\title{
Anti-apoptotic proteins BCL-2, MCL-1 and A1 summate collectively to maintain survival of immune cell populations both in vitro and in vivo
}

\author{
Emma M Carrington ${ }^{\star, 1,2}$, Yifan Zhan ${ }^{1,2}$, Jamie L Brady ${ }^{1,2}$, Jian-Guo Zhang ${ }^{1,2}$, Robyn M Sutherland ${ }^{1,2}$, Natasha S Anstee ${ }^{1,2}$, \\ Robyn L Schenk ${ }^{1,2}$, Ingela B Vikstrom ${ }^{1}$, Rebecca B Delconte ${ }^{1,2}$, David Segal ${ }^{1,2}$, Nicholas D Huntington ${ }^{1,2}$, Philippe Bouillet ${ }^{1,2}$, \\ David M Tarlinton ${ }^{1,2,3}$, David CS Huang ${ }^{1,2}$, Andreas Strasser ${ }^{1,2}$, Suzanne Cory ${ }^{1,2}$, Marco J Herold ${ }^{1,2}$ and Andrew M Lew ${ }^{\star, 1,2,4}$
}

Survival of various immune cell populations has been proposed to preferentially rely on a particular anti-apoptotic BCL-2 family member, for example, naive T cells require BCL-2, while regulatory $T$ cells require MCL-1. Here we examined the survival requirements of multiple immune cell subsets in vitro and in vivo, using both genetic and pharmacological approaches. Our findings support a model in which survival is determined by quantitative participation of multiple anti-apoptotic proteins rather than by a single anti-apoptotic protein. This model provides both an insight into how the sum of relative levels of anti-apoptotic proteins BCL-2, MCL-1 and A1 influence survival of T cells, B cells and dendritic cells, and a framework for ascertaining how these different immune cells can be optimally targeted in treatment of immunopathology, transplantation rejection or hematological cancers.

Cell Death and Differentiation (2017) 24, 878-888; doi:10.1038/cdd.2017.30; published online 31 March 2017

The BCL-2 family can be envisaged as a tripartite apoptosis control system comprising one set of anti-apoptotic and two sets of pro-apoptotic proteins, which interact to determine whether cells live or die in many pathophysiological states ${ }^{1-4}$ (Figure 1a). The five known anti-apoptotic members (BCL-2, $B C L-X L, B C L-W, M C L-1$ and $A 1 / B F L-1)$ share similarity in four $\mathrm{BCL}-2$ homology $(\mathrm{BH})$ domains. The pro-apoptotic members can be further sub-divided into 'initiators' that share homology only in the $\mathrm{BH} 3$ region (e.g., BIM, PUMA; see below) and 'effectors' that share similarities in all four $\mathrm{BH}$ domains, viz. BAX and BAK. BAX/BAK elicit mitochondrial outer membrane permeabilization, releasing cytochrome $c$ (and other apoptogenic factors; e.g., SMAC/DIABLO) into the cytosol to promote apoptosome formation and activation of the caspase cascade causing cellular demolition. ${ }^{5}$ The main function of antiapoptotic BCL-2 proteins is to restrain pro-apoptotic BAX/ BAK, thus preserving mitochondrial outer membrane integrity. This is achieved by direct binding and sequestration of proapoptotic $\mathrm{BH} 3-o n l y$ proteins that possess the ability to directly or indirectly activate $\mathrm{BAX} / \mathrm{BAK}$. The $\mathrm{BH}$-only proteins include at least eight members (BID, BIM, PUMA/BBC3, BAD, NOXA/PMAIP, BIK/BLK/NBK, BMF and HRK/DP5). Upon stress these proteins, transcriptionally induced or posttranscriptionally activated, bind anti-apoptotic members thereby unleashing BAX/BAK from their restraint. ${ }^{6}$ Certain $\mathrm{BH} 3-$ only proteins (e.g., BIM, PUMA) have been reported to also directly activate $\mathrm{BAX} / \mathrm{BAK}$, although this may not be obligatory. ${ }^{6-9}$
Binding studies have revealed that the capacity for different $\mathrm{BH} 3-$ only proteins to bind anti-apoptotic proteins is not equal. $^{8,10}$ Some BH3-only proteins (BIM, PUMA, truncated BID) bind avidly to all five anti-apoptotic proteins, whereas others are more selective. For example, BAD only binds to BCL-2, BCL-XL and BCL-W but not MCL-1 or A1/BFL-1, whereas NOXA does the converse. Moreover, it has been reported that distinct anti-apoptotic proteins also differ in their ability to restrain $\mathrm{BAX}$ or $\mathrm{BAK}$; for example, BCL-2 only being able to bind and restrain BAX but not BAK. ${ }^{11}$ Simplistically, this would imply there should be qualitative differences in the capacity of at least some anti-apoptotic proteins to block death, a finding indirectly supported by the reciprocal pattern of expression often observed between different anti-apoptotic proteins throughout immune cell development (e.g., low MCL-1 and high BCL-2 in naive B cells, but high MCL-1 and low BCL-2 in germinal center B cells). ${ }^{12-14}$

$\mathrm{BH} 3-$ only protein binding selectivity has formed the basis of rational drug design strategies to antagonize distinct antiapoptotic BCL-2 family members. First-generation compounds ABT-737 and ABT-263/navitoclax antagonize BCL-2, $\mathrm{BCL}-\mathrm{XL}$ and $\mathrm{BCL}-\mathrm{W} .^{15-17}$ The second-generation compound ABT-199/venetoclax/venclexta, selective for BCL-2 alone, ${ }^{18}$ has proven highly effective in the treatment of certain leukemias and lymphomas ${ }^{19-21}$ and received FDA approval in April 2016 for treating refractory chronic lymphocytic leukemia with $17 p$ chromosomal deletion. However, factors predicting cell sensitivity, particularly in vivo, and what role

\footnotetext{
${ }^{1}$ The Walter and Eliza Hall Institute of Medical Research, Parkville, VIC 3052, Australia; ${ }^{2}$ Department of Medical Biology, University of Melbourne, Parkville, VIC 3010 , Australia; ${ }^{3}$ Department of Immunology \& Pathology, Monash University, Melbourne, VIC 3004, Australia and ${ }^{4}$ Department of Microbiology \& Immunology, University of Melbourne, Parkville, VIC 3010, Australia

${ }^{*}$ Corresponding author: E Carrington or A Lew, The Walter and Eliza Hall Institute of Medical Research, 1G Royal Parade, Parkville, VIC 3052, Australia. Tel: +61 39345 2555; Fax: +61 39347 0852; E-mail: carrington@ wehi.edu.au or lew@wehi.edu.au

Received 17.11.16; revised 09.2.17; accepted 10.2.17; Edited by H Steller; published online 31.3.2017
} 
a

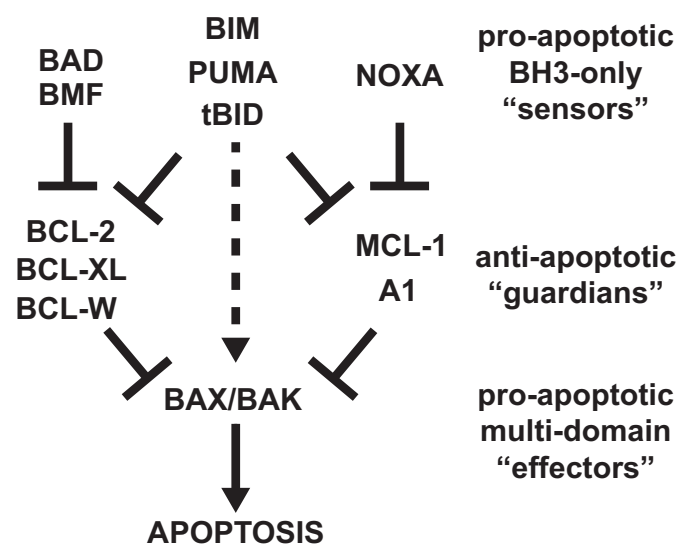

b

\begin{tabular}{|l|l|l|}
\hline \multicolumn{1}{|c|}{ Immune cell } & \multicolumn{1}{c|}{$\begin{array}{c}\text { Critical } \\
\text { molecule }\end{array}$} & \multicolumn{1}{c|}{ Ref. } \\
\hline Naïve B cell & BCL-2 & $24,25,26$ \\
Naïve T cell & & $24,25,26$ \\
pDC & & 27 \\
\hline B cell & MCL-1 & 34,39 \\
GC B cell & & 14 \\
Plasma cell & & 28 \\
Naïve T & & 34 \\
Memory T & & 34,35 \\
T reg & & 30 \\
NK & & 29 \\
pDC & & 27 \\
Neutrophil & & 31 \\
HSC & & 33 \\
\hline cDC & A1 & 27,37 \\
\hline Erythroid progenitors & BCL -XL & 32 \\
Platelets & & 22,23 \\
\hline
\end{tabular}

Figure $1 \mathrm{BCL}-2$ family and immune cell subsets. (a) Schematic of the BCL-2 family proteins and their functions in the intrinsic mitochondrial pathway of apoptosis. The anti-apoptotic 'guardians' (BCL-2, BCL-XL, BCL-W, MCL-1 and A1) promote cell survival by preventing mitochondrial outer membrane permeabilization by the downstream pro-apoptotic 'effectors' BAX/BAK. Mitochondrial outer membrane permeabilization causes release of cytochrome $c$ and other apoptogenic proteins that promote activation of the caspase cascade that mediates cell demolition. The proapoptotic BH3-only 'sensors' promote death by selectively antagonizing the function of the anti-apoptotic proteins and/or directly activating BAX/BAK. Direct activation of BAX/BAK by BIM, PUMA and truncated BID may not be obligatory for death induction and hence is displayed as a dashed arrow. (b) Apparent differential dependency of distinct immune cells subsets on individual anti-apoptotic BCL-2 family proteins for survival

each anti-apoptotic member plays are not definitively understood.

Besides selectivity of binding between some $\mathrm{BH}$-only proteins to anti-apoptotic BCL-2 family members, arguably the most cogent case for qualitative differences in the antiapoptotic molecules is the apparent differential dependence by many immune cell subsets on individual proteins for survival. For example, platelets were found to be reliant on BCL-XL. ${ }^{22,23}$ Naive T cells, naive $B$ cells and plasmacytoid dendritic cells ( $p D C$ but not conventional $D C, c D C$ ) rely on BCL-2. ${ }^{24-27}$ Conversely, germinal center $\mathrm{B}$ cells, ${ }^{14}$ plasma cells, ${ }^{28} \mathrm{NK}$ cells ${ }^{29}$ and regulatory T cells ${ }^{30}$ depend on MCL-1 (summarized in Figure 1b). One conspicuous extrapolation of these studies is that the anti-apoptotic proteins play distinct roles in these subsets (qualitative model). The alternative model is that cell survival is safeguarded by quantitative expression of the total set of BCL-2 family members (quantitative model), but because of differential expression among the subsets, one family member may appear more important than another. This latter model would predict that reduced levels or antagonism of one anti-apoptotic member may be compensated for by increased levels of another; that is, implying there is functional redundancy (at least partially) among the anti-apoptotic BCL-2 proteins.

Herein, we looked at the impact of manipulating the amount of different anti-apoptotic BCL-2 family members in immune cells. We found that by reducing endogenous MCL-1 and/or A1, we could sensitize cells to death by BCL-2 antagonism. Conversely, increasing BCL-2 or MCL-1 could compensate for reduced levels of either protein. These findings reveal that rather than autonomously controlling survival of a particular cell type, individual anti-apoptotic proteins contribute quantitatively to survival outcome.

\section{Results}

Deficiency of MCL-1 can be compensated by increased levels of BCL-2. We have previously shown that haploinsufficiency of $\mathrm{Mcl}-1\left(\mathrm{Mcl1}^{+/-}\right)$significantly reduced $\mathrm{DC}$ populations in vivo. ${ }^{27}$ To determine whether this loss was MCL-1-specific, we tested whether increasing the level of BCL-2 could compensate $\mathrm{Mcl}-1$ haplo-insufficiency. We crossed ${\mathrm{Mcl}-1^{+/-}}$mice to mice overexpressing $\mathrm{BCL}-2$ in all hematopoietic cells ( $B C L-2 \mathrm{tg})$ and then generated bone marrow (BM) chimeras from resultant offspring. $\mathrm{Mcl}-1$ haploinsufficiency within the immune cell compartment resulted in reduced numbers of both $\mathrm{pDC}$ and $\mathrm{CDC}$ (Figure 2a), as previously reported. ${ }^{27} \mathrm{~B}$-cell but not T-cell numbers were also significantly decreased. Upon BCL-2 overexpression, the numbers of all cell populations that were diminished in the $\mathrm{Mcl}-1^{+/-}$mice were equivalent to or even above those seen

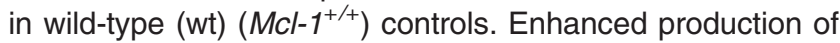
pDC and B cells in BM did not appear to be responsible for restoration of cells in the periphery as concurrent organ analysis revealed BM was only mildly affected by BCL-2 overexpression compared to spleen and other peripheral sites such as blood (Supplementary Figure 1). Importantly, western blot analysis of purified $B$ cells, pDC and $\mathrm{CDC}$ confirmed reduced MCL-1 and increased BCL-2 expression in cells from $\mathrm{BCL}-2 \mathrm{tg} / \mathrm{Mcl}-1^{+/-}$mice. There was no compensatory increase in $A 1$, discounting this as a factor contributing to rescue (Figure $2 \mathrm{~b}$ ). This is an important finding as A1 has more similar binding specificity to MCL-1 than other anti-apoptotic proteins (e.g., they both bind NOXA but not $B A D)$. Interestingly, BCL-2 overexpression in $B$ cells and $\mathrm{pDC}$ appeared to coincide with reduced MCL-1 protein (Figure $2 b$ ). Overexpression of BCL-2 could also fully protect B cells and pDC in culture from apoptosis induced by pharmacological inhibition of MCL-1 by a recently described highly specific $\mathrm{BH} 3$ mimetic $^{31}$ (Figure 2c). Importantly, sensitivity to this 

total B cells $\mathrm{CD}^{+}{ }^{+} \mathrm{T}$ cells $\mathrm{CD}^{+} \mathrm{T}$ cells

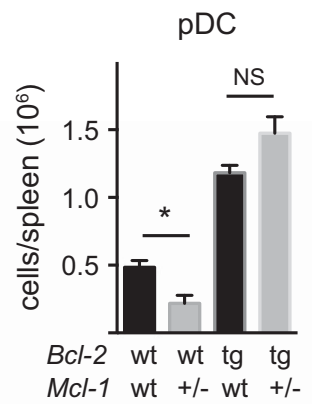
$\mathrm{CDC}$

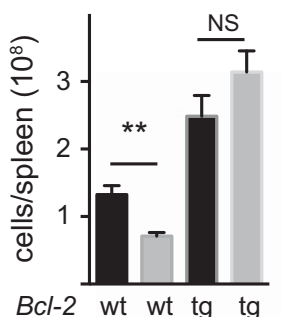

$\mathrm{Mcl}-1$ wt +/- wt +/-
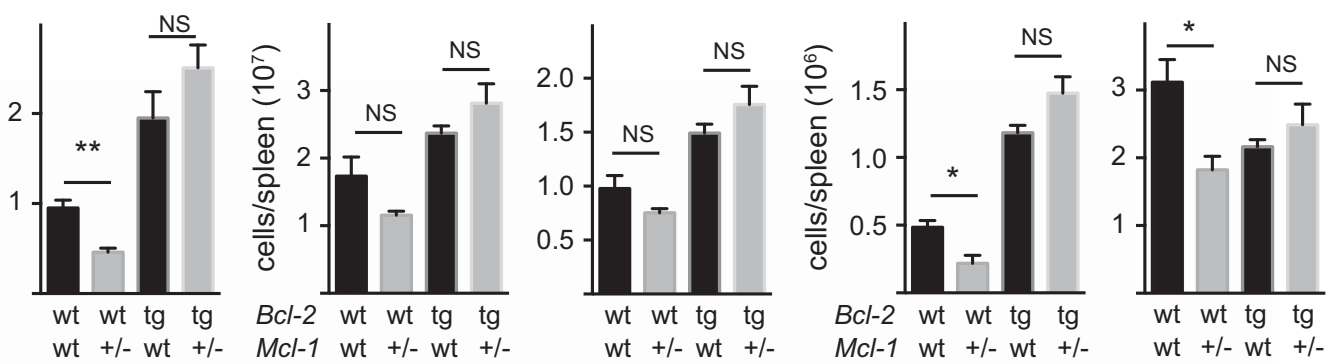

b
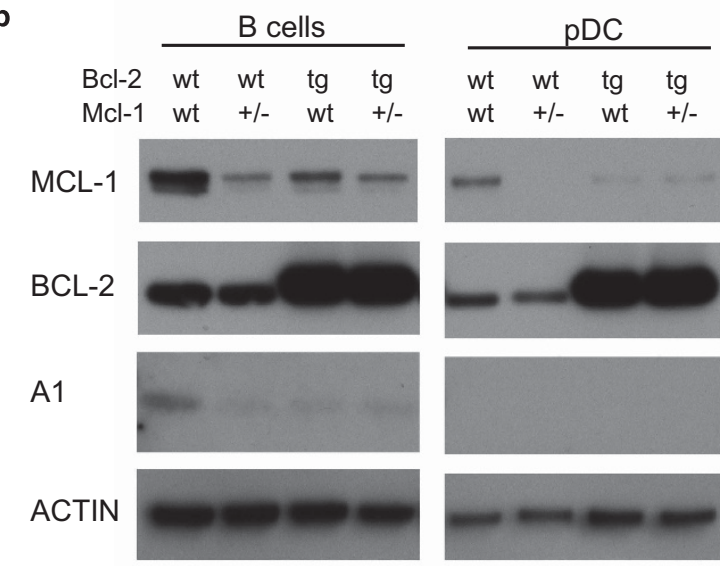

\begin{tabular}{llll}
\multicolumn{4}{c}{ CDC } \\
\hline wt & wt & tg & tg \\
wt & $+/-$ & wt & $+/-$
\end{tabular}
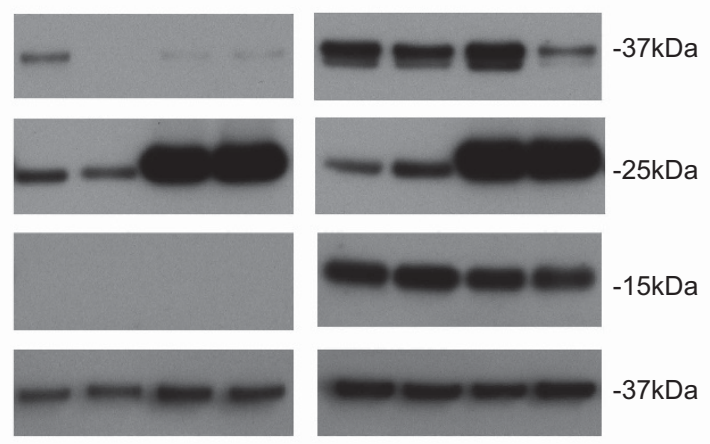

$-37 \mathrm{kDa}$

c
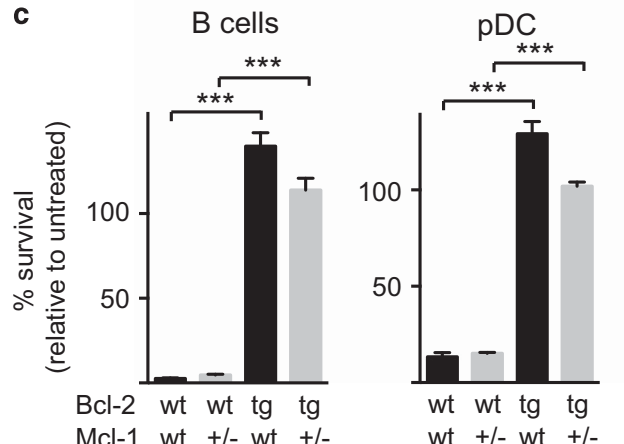

$\mathrm{cDC}$

Mcl-1 wt +/- wt +/-

wt +/- wt +/-
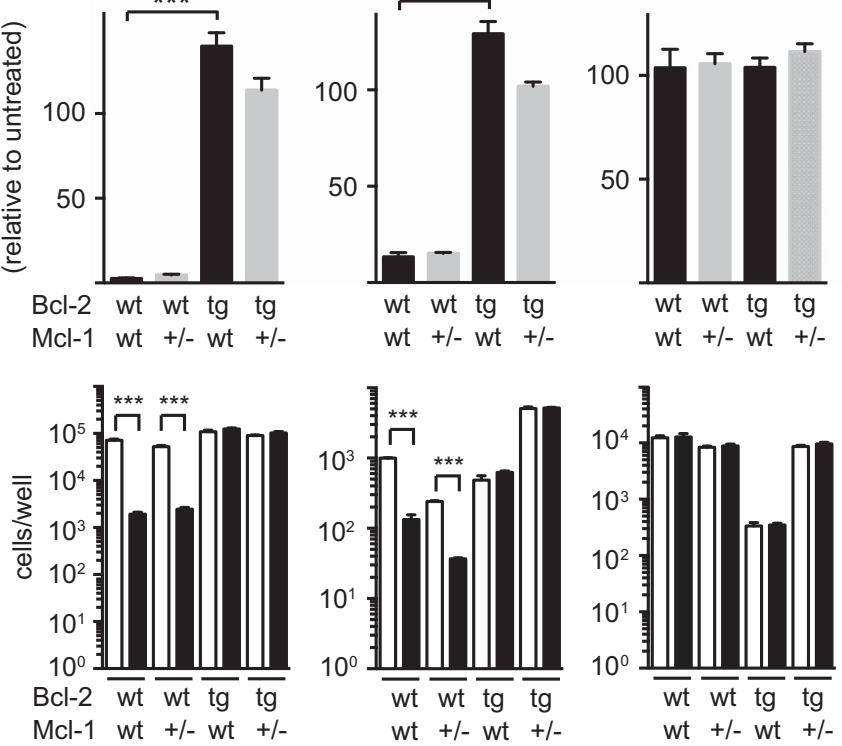

Figure 2 Deficiency of MCL-1 in leukocyte subsets can be compensated for by increased amounts of BCL-2. Haplo-insufficient $M C l-1^{+/-}$mice were bred to $B C L-2$ tg mice to generate $\mathrm{B} 6(\mathrm{wt}), \mathrm{Mcl}-1^{+/-}, \mathrm{BCL}-2$ tg and ${\mathrm{MCl}-1^{+/-}}_{3} \mathrm{BCL}-2$ tg. BM chimeras were generated from 8-week-old resultant offspring (a) Live $\mathrm{B}$ cells, $\mathrm{CD} 4^{+} \mathrm{T}$ cells, $\mathrm{CD}^{+} \mathrm{T}$ cells, $\mathrm{pDC}$ and $\mathrm{CDC}$ were enumerated by PI staining and flow cytometry. Data shown are from a single representative experiment of three experiments each with $n=4$ animals; mean \pm S.E.M. analyzed using a two-tailed Student's $t$-test. ${ }^{*} P<0.05,{ }^{* *} P<0.01,{ }^{* * *} P<0.001$, NS not significant. (b) Western blot analysis was performed on sorted $\mathrm{B}$ cells, pDCs and CDCs to assess the amounts of MCL-1, BCL-2, A1 and $\beta$-actin (loading control) proteins. (c) Increased BCL-2 expression can compensate for $\mathrm{MCL}-1$ deficiency in vitro. wt, $\mathrm{Mcl}-1^{+/-}, \mathrm{BCl}-2 \operatorname{tg}$ and $\mathrm{Mcl}-1^{+/-} ; \mathrm{BCL}-2$ tg spleen cells were cultured with or without treatment of $1 \mu \mathrm{M} \mathrm{MCL}-1$ inhibitor. After $16 \mathrm{~h}$, cells were recovered and survival of $\mathrm{B}$ cells, $\mathrm{pDC}$ and $\mathrm{CDC}$ determined by PI staining and flow cytometry. Data are shown as the proportion (\%) of the average number of live cells isolated from untreated cultures for each strain (\% survival) (top panel) or cells recovered/well (bottom panel) as mean \pm S.E.M. Data shown are from a single representative experiment of three experiments of $n=3$ 
inhibitor was preserved under conditions of reduced MCL-1

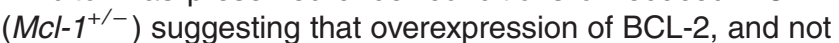
deviation from MCL-1 dependency, was responsible for protection in the $B C L-2 \mathrm{tg} / \mathrm{Mcl}-1^{+/-}$cells (Figure 2c). All $\mathrm{CDC}$ tested were refractory to MCL-1 inhibitor (Figure $2 \mathrm{c}$ ), suggesting that although initially dependent on MCL-1, 27 once fully differentiated, $\mathrm{CDC}$ are no longer fully reliant on MCL-1 for their survival. Taken together, these data suggest that despite being the targets of different $\mathrm{BH} 3$-only proteins (e.g., NOXA but not BAD binds MCL-1; the converse for $B C L-2)$ increasing levels of BCL-2 could compensate for reduced amounts of $\mathrm{MCL}-1$.

Partial deficiency in Mcl-1 unmasks the sensitivity of cells to BCL-2 antagonism. Since increased BCL-2 could mitigate the effect of haplo-insufficiency in $M c l-1$, we hypothesized that antagonism of endogenous BCL-2 would exacerbate the effect of partial Mcl-1 deficiency. Indeed, when $\mathrm{Mcl}-1^{+/-}$splenocytes were cultured in the presence of the BCL-2 inhibitor ABT-199, ${ }^{18}$ B cells, T cells and pDC died significantly more over a range of doses than the corresponding wt control cells treated with ABT-199 (Figure 3a). This was also true in vivo when mice were given a single $100 \mathrm{mg} / \mathrm{kg}$ body weight dose of ABT-199 and spleens analyzed $24 \mathrm{~h}$ following treatment, particularly in the pDC compartment where inhibition of BCL-2 ablated almost all pDC in $\mathrm{Mcl}-1^{+/-}$ mice (Figure 3b). Although global $\mathrm{Mcl}-1$ haplo-insufficiency per se approximately halved the splenic T-cell numbers in vivo (Figure 3b), additional inhibition of BCL-2 by ABT-199 treatment substantially increased death of these cells, with a further four-fold reduction in $\mathrm{CD}^{+}$and $\mathrm{CD}^{+} \mathrm{T}$ cells (Figure $3 b$ ). This effect was also seen in B cells, but was less remarkable in $\mathrm{cDC}$; that is, there was only a modest albeit significant reduction in the $\mathrm{CDC}$ numbers seen in the spleens of ABT-199-treated $\mathrm{MCl}-1^{+/-}$mice compared to vehicletreated $\mathrm{MCl}-1^{+/-}$mice (Figure $3 \mathrm{~b}$ ).

We had previously found that MCL-1 is critical for NK cell ${ }^{29}$ and Treg cell ${ }^{30}$ survival by demonstrating that these leukocyte subsets are selectively ablated by $\mathrm{Mcl}-1$ deletion using cell type-restricted Cre transgenes (Nkx-Cre or FoxP3-Cre). Therefore, we decided to test the impact of ABT-199 (BCL-2 inhibitor) treatment on these 'MCL-1 dependent' cell subsets. We found that for NK cells, either BCL-2 inhibition or Mcl-1 haplo-insufficiency significantly reduced numbers in vivo compared to vehicle-treated controls; however, the combination of BCL-2 inhibition and $\mathrm{Mcl}-1$ haplo-insufficiency reduced NK numbers even further compared with either survival impairment alone (Figure 3c). Similarly, Treg numbers were more substantially reduced by combined ABT-199 treatment and $\mathrm{Mcl}-1$ haplo-insufficiency than by either impairment alone (Figure 3d).

Collectively, these results reveal that in multiple cell types endogenous BCL-2 and MCL-1 have overlapping, rate-limiting functions in cell survival.

BCL-2 inhibition can be compensated by increased MCL-1 levels. We had shown above that BCL-2 overexpression could compensate for reduced MCL-1 levels. Next, we wanted to determine whether increased MCL-1 levels could protect cells from apoptosis induced by antagonism of endogenous $\mathrm{Bcl}-2$. As we had previously shown that $B$ cells, $T$ cells and $\mathrm{pDC}$, but not $\mathrm{CDC}$, were sensitive to $B C L-2$ inhibition, ${ }^{26,27}$ we examined the in vitro response of these cell types to ABT-199, when MCL-1 was overexpressed ( $\mathrm{Mcl}-1 \mathrm{tg})$. All three ABT-199-sensitive cell types ( $B$ cells, $T$ cells and $\mathrm{pDC}$ ) were protected from death over a range of doses with significantly more $\mathrm{Mcl}-1 \mathrm{tg}$ cells recovered after treatment compared to wt control cells (Figure 4a). This protection was also evident in vivo when animals were gavaged with a high dose of ABT-199 (100 mg/kg body weight; five daily doses), such that all cell types were completely protected from depletion in $\mathrm{Mcl}-1 \mathrm{tg}$ animals, whereas substantial portions of these cell types were lost in the ABT-199-treated wt controls (Figure 4b). This was particularly remarkable for $\mathrm{pDC}$, which are normally exquisitely sensitive to ABT-199 but were completely protected by MCL-1 overexpression both in vitro (Figure 4a) and in vivo (Figure $4 \mathrm{~b}$ ). As expected, ${ }^{27}$ wt $\mathrm{cDC}$ were minimally affected by ABT-199 treatment at all doses tested. Taken together, these data demonstrate that increased levels of MCL-1 can compensate for loss of BCL-2 function, both in vitro and in vivo.

Loss of A1 unmasks the sensitivity of CDC to BCL-2 antagonism. The one immune cell whose survival is known to be reliant on $A 1$ is the $\mathrm{CDC}$, a finding replicated in both the A1 knockdown mouse ${ }^{27}$ and genetically deficient mouse models ${ }^{32}$ and consistent with the inability of BCL-2 inhibitors to kill this subset (Figures 3 and 4; ref. 27). Therefore, we assessed whether $A 1$ deficiency (loss of all $A 1$ isoforms; ref. 32) could sensitize $C D C$ to $B C L-2$ antagonism. We first measured the amount of $\mathrm{A} 1, \mathrm{MCL}-1$ and $\mathrm{BCL}-2$ in splenic cDC from wt and $A 1^{-1-}$ animals confirming complete loss of A1 protein and no major expression differences of BCL-2 and MCL-1 in the $A 1^{-1-} \mathrm{CDC}$ compared to wt (Figure 5a). When splenocytes were cultured in the presence of ABT-199, $A 1^{-1-}$ CDC had significantly impaired survival (LD50 $\sim 30 \mathrm{nM}$ ) compared to wt cDCs, which remained unaffected by ABT-199 (Figure 5b). As expected, ${ }^{27} \mathrm{cDC}$ numbers in vivo were unaffected after ABT-199 gavage in wt mice. Untreated or vehicle-treated $A 1^{-1-}$ mice had modestly lower CDC numbers than wt animals as previously described. ${ }^{32}$ However, BCL-2 inhibition by ABT-199 gavage in $A 1^{-/-}$mice caused a dramatic loss of $\mathrm{CDC}$ numbers, reducing them to a third of the numbers found in vehicle-gavaged $A 1^{-/-}$controls (Figure $5 c$ ). These findings demonstrate that $A 1$ and $B C L-2$ have critical overlapping functions in the survival of $\mathrm{cDCs}$, revealing a previously undocumented role for BCL-2 both in culture and within the intact animal.

BCL-2 antagonism unmasks the sensitivity of $B$ and $\mathbf{T}$ lymphoid cells to the loss of A1. As previously reported, ${ }^{32,33}$ there was no significant difference in B- or T-cell numbers between wt and $A 1^{-/-}$mice (Figure $5 \mathrm{~d}$ ). Thus, at first glance one could conclude that $A 1$ is not important for the survival of $B$ and $T$ cells. However, we wanted to test our quantitative model, which predicts that when $A 1$ is very low or absent, other anti-apoptotic BCL-2 family members become limiting for safeguarding survival. In line with this hypothesis, when BCL-2 was inhibited, loss of 


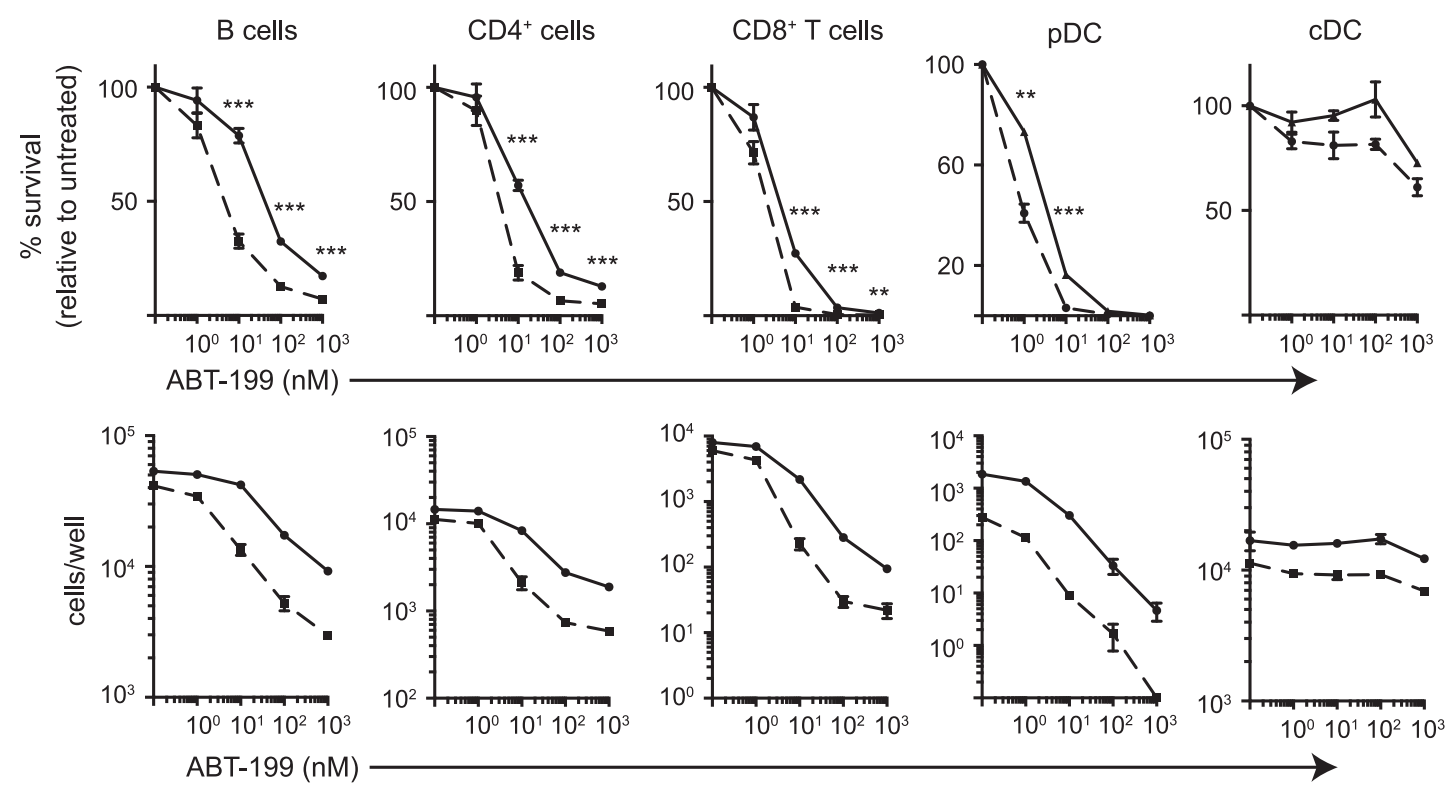

b
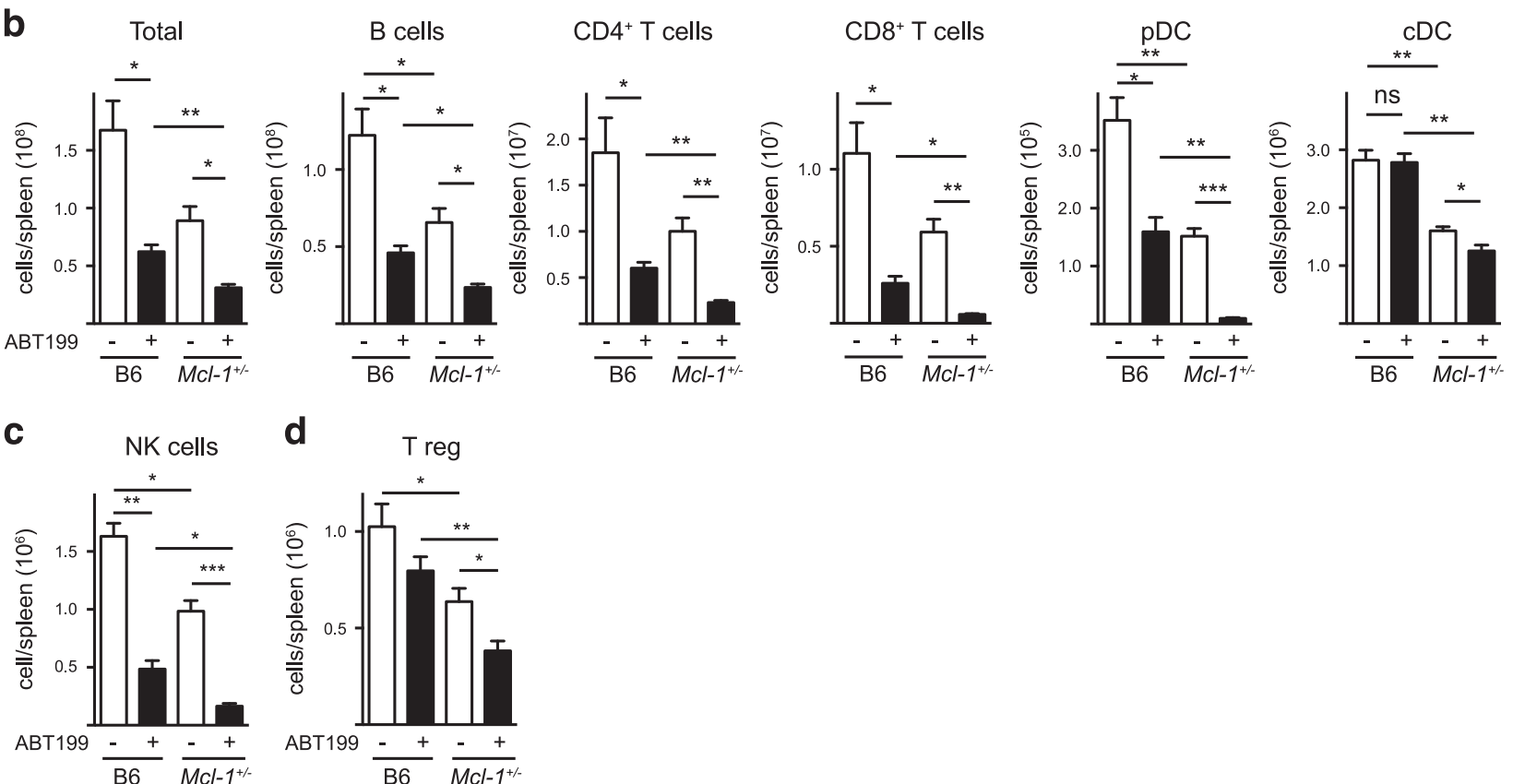

d $\quad$ reg

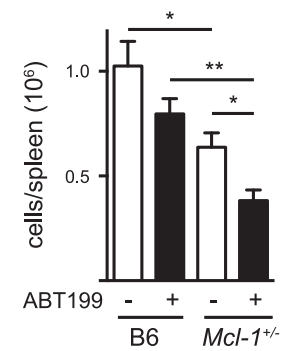

Figure 3 Haplo-insufficiency of MCl-1 unmasks sensitivity of immune cells to antagonism of BCL-2. (a) Reduced amounts of MCL-1 sensitize immune cells to death by Bcl-2 antagonism in vitro. Spleen cells from 8-week-old B6 wt (solid line) or MCl-1+/- littermates (dashed line) were cultured with the BCL-2 inhibitor ABT-199 at the indicated doses. After $16 \mathrm{~h}$, viable B cells, $\mathrm{CD}^{+} \mathrm{T}$ cells, $\mathrm{CD} 8^{+} \mathrm{T}$ cells, $\mathrm{pDCs}$ and $\mathrm{CDCs}$ were enumerated by PI staining and flow cytometry. Data are shown as the proportion (\%) of the average number of live cells isolated from untreated cultures for each strain (\% survival) (top panel) or cells recovered/well (bottom panel) as mean \pm S.E.M. Data shown are from a single representative experiment of three experiments of $n=3$. (b) Reduced amounts of MCL-1 sensitize cells to death induced by BCL-2 inhibition in vivo. 8-week-old B6 (wt) or

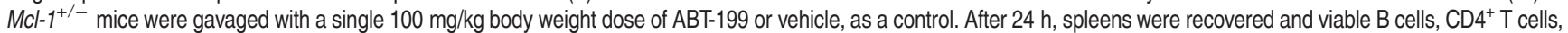
$\mathrm{CD}^{+} \mathrm{T}$ cells, pDC, cDC, NK cells (c), and Treg cells (d) were enumerated by PI staining and flow cytometry. Data show a single representative experiment of three experiments; $n=3-4$ animals; mean \pm S.E.M. All data analyzed using a two-tailed Student's $t$-test. ${ }^{*} P<0.05,{ }^{* \star} P<0.01,{ }^{* \star *} P<0.001$, ns $=$ not significant

A1 resulted in a halving of $B$ - and T-cell numbers, compared with ABT-199-treated wt mice (Figure 5d). From these findings, we conclude that at physiological levels, A1 can promote survival of $B$ and $T$ cells, but is functionally redundant in cells from wt mice as there is sufficient BCL-2 to maintain survival.
Loss of A1 unmasks the sensitivity of cells to reduced levels of MCL-1. Given that loss of A1 could sensitize cells to BCL-2 antagonism, we were interested to examine whether the same was true for MCL-1 antagonism. Indeed, when splenocytes were cultured in the presence of MCL-1 inhibitor, $A 1^{-/-} \mathrm{CDC}$ and $\mathrm{T}$ cells displayed significantly more 

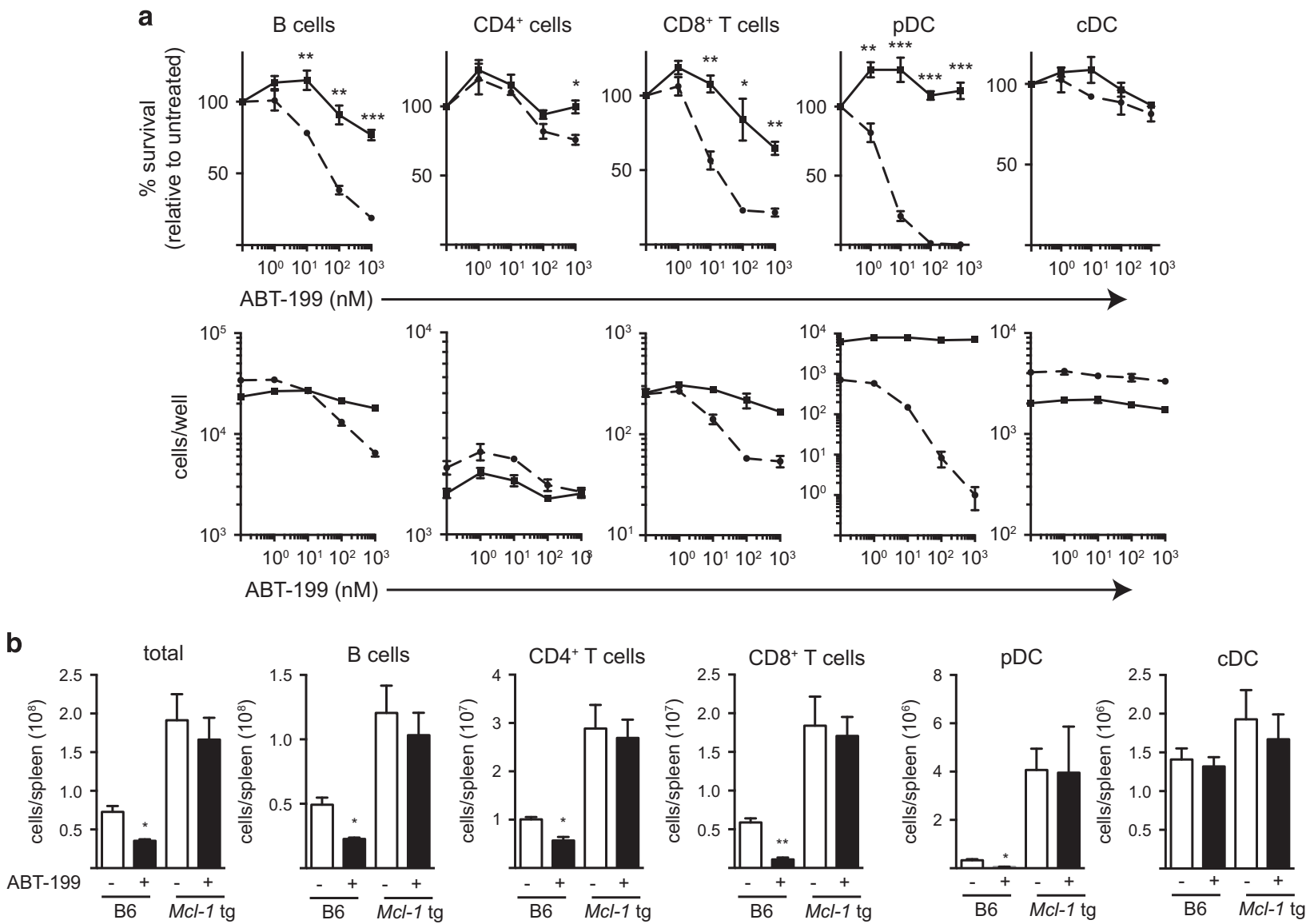

Figure 4 Cells can be rendered resistant to BCL-2 antagonism by increased levels of MCL-1. (a) Increased amounts of MCL-1 protect immune cells from death induced by BCL-2 inhibition (ABT-199 treatment) in vitro. Spleen cells from 12-14 week old B6 (wt) (dashed line) or Mcl-1 tg littermates (solid line) were cultured with the BCL-2 inhibitor ABT-199 at the indicated doses. After $16 \mathrm{~h}$, viable B cells, CD4 ${ }^{+} \mathrm{T}$ cells, CD8 ${ }^{+} \mathrm{T}$ cells, $\mathrm{pDC}$ and $\mathrm{CDC}$ were enumerated by PI staining and flow cytometry. Data are shown as the proportion (\%) of the average number of live cells isolated from untreated cultures for each strain (\% survival) (top panel) or cells recovered/well (bottom panel) as mean \pm S.E.M. Data shown are from a single representative experiment of three experiments of $n=3$. (b) Increased amounts of MCL-1 protect cells from death induced by the BCL-2 inhibitor ABT-199 in vivo. 12-14-week-old B6 (wt) or Mcl-1 tg littermate mice were gavaged with five daily doses of $100 \mathrm{mg} / \mathrm{kg}$ body weight ABT-199 or vehicle, as a control. After treatment spleens were recovered and viable B cells, $C D 4^{+} \mathrm{T}$ cells, $\mathrm{CD} 8^{+} \mathrm{T}$ cells, $\mathrm{pDC}$ and $\mathrm{CDC}$ remaining in the organ were assessed by PI staining and flow cytometry. Data show a single representative experiment of three experiments; $n=3-4$ animals \pm S.E.M. All data were analyzed using a two-tailed Student's $t$-test. ${ }^{*} P<0.05,{ }^{* *} P<0.01$, ${ }^{\star * \star} P<0.001$

death over the dose range than their wt counterparts (Figure 6a). As noted above (Figure 2c), B cells were so sensitive to MCL-1 inhibition in vitro that under the conditions used it was not possible to reveal any meaningful synergistic or additive effect between $\mathrm{A} 1$ loss and MCL-1 inhibition. Notably, the increased death of $A 1^{-/}$cells evinced by BCL-2 inhibition (using ABT-199) could be further exacerbated by genetically reducing levels of $\mathrm{Mcl}-1$ (haplo-insufficiency). When splenocytes that lacked $\mathrm{A} 1$ and were also haploinsufficient for $\mathrm{MCl}-1\left(\mathrm{A1}^{-/-} ; \mathrm{MCl}^{-1^{+/-}}\right)$were treated with ABT-199 in vitro, cDCs and T cells were significantly more sensitive to treatment than their wt counterparts or cells possessing either deficiency alone $\left(A 1^{-/-} ; \mathrm{MCl}^{-1^{+/+}}\right.$or $A 1^{+/+}$;

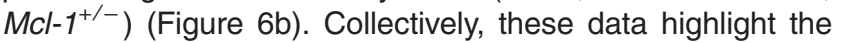
collaborative effect BCL-2, MCL-1 and $\mathrm{A} 1$ have on maintenance of cell survival, cogently supporting a quantitative model of anti-apoptotic protein function, at least in immune cell subsets.

\section{Discussion}

The survival of distinct immune cell subsets is differentially dependent on select anti-apoptotic BCL-2 family proteins. ${ }^{14,22,26,27,29}$ However, the reasons underlying this reliance are not fully elucidated. There are at least two plausible scenarios. First, dependence on a particular antiapoptotic protein could reflect inimitable characteristics offered by the protein. Thus, the function of a given antiapoptotic member could not be replaced by another. For example, the difference in affinity between MCL-1 versus BCL-2 for NOXA could support this model. Second, dependence could reflect differential expression of anti-apoptotic BCL-2 family members within a cell type and the functional load the collective set of proteins has to bear (Quantitative model). In this scenario, sequentially removing individual antiapoptotic BCL-2 family members would progressively reduce the total load available to neutralize the pro-apoptotic 


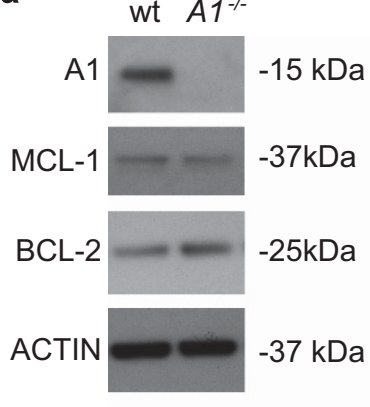

cDC in vitro

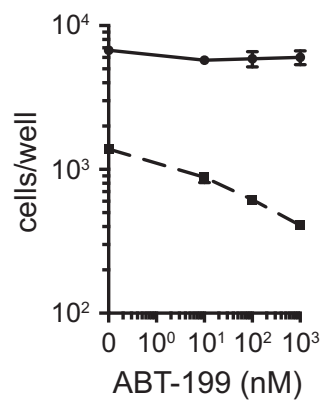

C

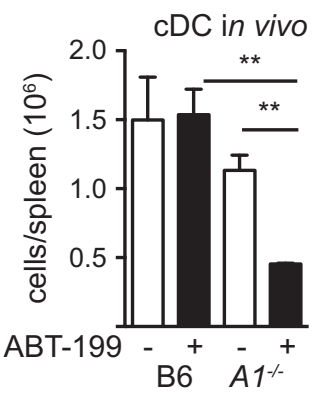

d

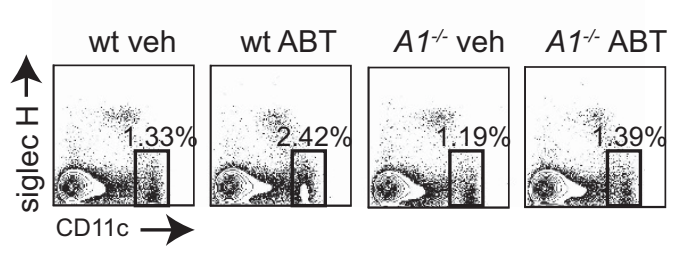

total

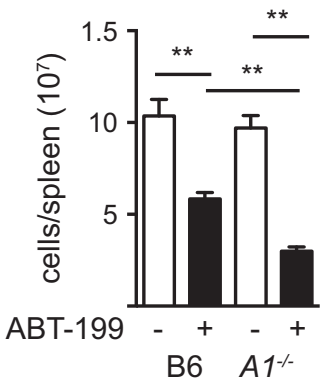

B cells

T cells
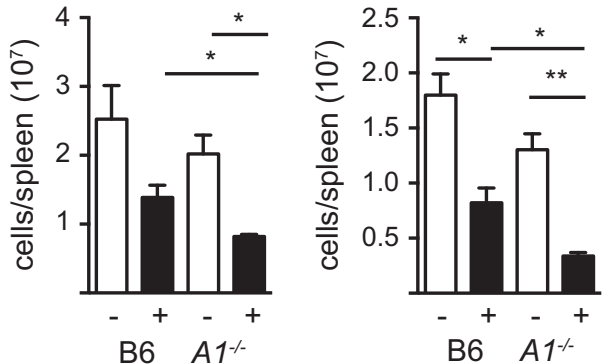

Figure 5 Loss of $A 1$ sensitizes immune cells to BCL-2 antagonism (a) Loss of A1 sensitizes CDCs to death induced by the BCL-2 inhibitor ABT-199 both in vitro and in vivo. Spleens were isolated from 9-week-old B6 and $\mathrm{A}^{-1-}$ littermates. (a) Western blot analysis was performed on sorted CDCs to assess the amounts of MCL-1, BCL-2, A1 and $\beta$-actin (loading control) proteins confirming loss of A1 protein expression in knockout cells. (b) Spleen cells from B6 (wt) (solid line) or $A 1^{-/}$littermates (dashed line) were cultured with the BCL-2 inhibitor ABT-199 at the indicated dose. After $16 \mathrm{~h}$, viable cDCs were enumerated by PI staining and flow cytometry. Data are shown as the proportion (\%) of the average number of live cells isolated from untreated cultures for each strain (\% survival) (left panel) or cells recovered/well (right panel) as mean \pm S.E.M. Data shown are from a single representative experiment of three experiments of $n=3$. (c) 10-week-old B6 (wt) or $A 1^{-/-}$mice were gavaged with five daily doses of $50 \mathrm{mg} / \mathrm{kg}$ body weight ABT-199 or vehicle, as a control. Following treatment, spleens were recovered and CDCs were enumerated by PI staining and flow cytometry. Representative flow cytometry plots show percentage of $C D C$ per spleen preparation. (d) Loss of A1 sensitizes T and B lymphocytes to death induced by the BCL-2 inhibitor ABT-199. 10-week-old B6 (wt) or A1 ${ }^{-/-}$ mice were gavaged with five daily doses of $50 \mathrm{mg} / \mathrm{kg}$ body weight ABT-199 or vehicle, as a control. Following treatment, spleens were recovered and total cellularity, B cells and T cells were enumerated by PI staining and flow cytometry. In vitro data show a single representative experiment of three experiments of $n=3$. In vivo data show a single representative experiment of three experiments; $n=3$ animals; mean \pm S.E.M. All data were analyzed using a two-tailed Student's $t$-test. ${ }^{*} P<0.05,{ }^{* *} P<0.01,{ }^{* \star *} P<0.001$

members present within that cell, eventually tipping the outcome in favor of death. In cells with a high propensity for death, one could speculate that the total levels of the antiapoptotic BCL-2 family members might be limiting, such that genetically removing or pharmacologically inhibiting a single member may be sufficient to kill a particular subset. Conversely, more resistant cells may require inactivation of multiple anti-apoptotic BCL-2 family proteins.

Herein, we present evidence that immune cell survival is governed by collaboration between multiple anti-apoptotic BCL-2 family members within a given cell, acting to preserve viability by neutralizing the pro-apoptotic members present. In accordance with a quantitative model, we found that apoptosis could be initiated by individually targeting abundantly expressed anti-apoptotic proteins within a given immune cell population. Cell killing could be enhanced or reduced, respectively, by sequentially subtracting or adding the function of additional anti-apoptotic BCL-2 family members. For example, in pDCs and B cells, both BCL-2 and MCL-1 are limiting ${ }^{26,27,34}$ and therefore genetic loss or pharmacological inhibition of either results in increased sensitivity to loss or antagonism of the other (Figure 3b). Moreover, BCL-2 or MCL-1 overexpression prevents cell death caused by loss or drug-mediated inhibition of the other (e.g., $\mathrm{Mcl}-1$ 
a
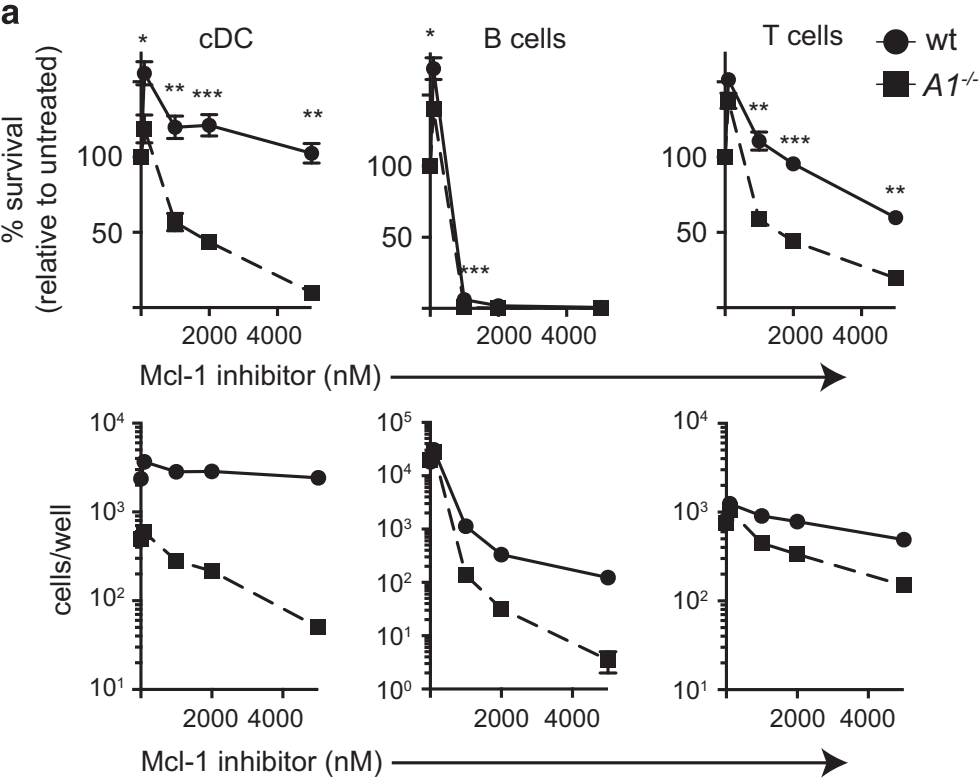

b

Mcl-1 inhibitor (nM)
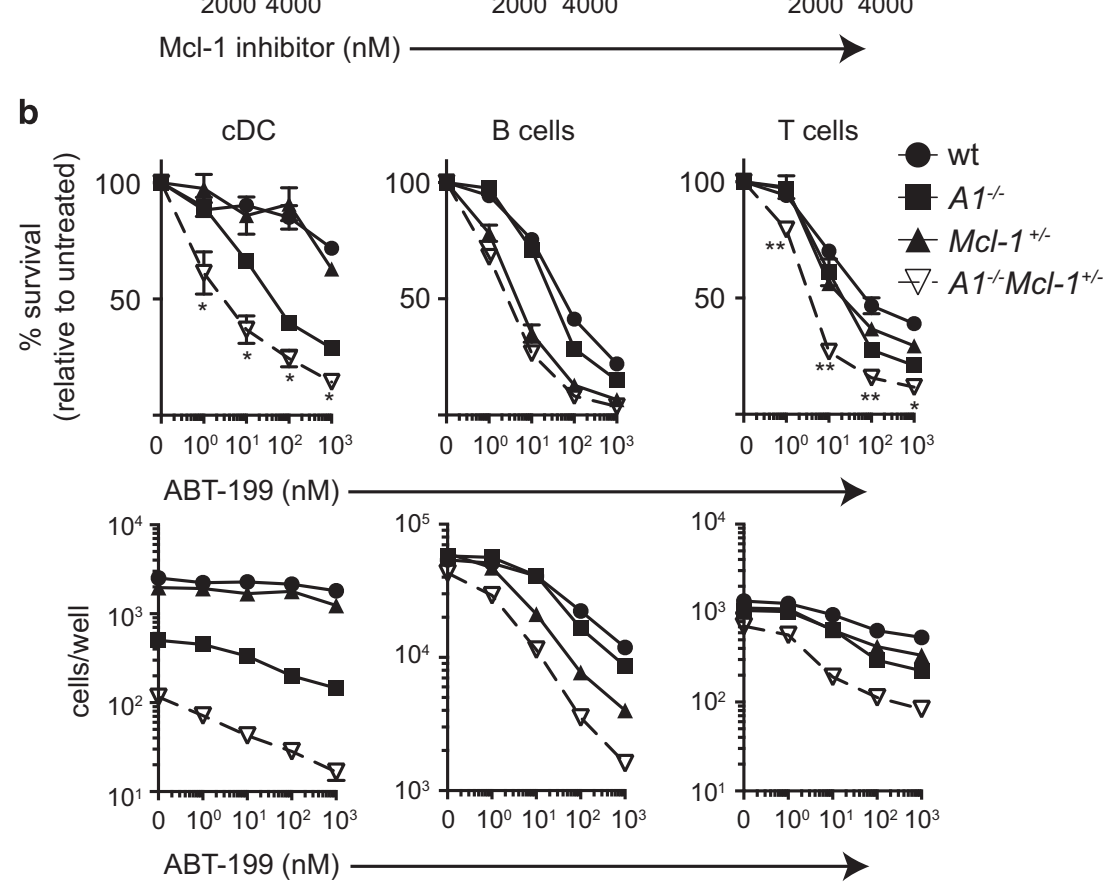

Figure 6 Loss of A1 sensitizes immune cells to reduced levels of MCL-1. (a) Loss of A1 sensitizes immune cells to death induced by reduced levels of MCL-1. Spleen cells from 8-week-old B6 (wt) (solid line) or $A 1^{-/-}$littermates (dashed line) were cultured with MCL-1 inhibitor at the indicated doses. After $16 \mathrm{~h}$, viable cells were enumerated by PI staining and flow cytometry. Data show a single representative experiment of three experiments of $n=3$ (b) Spleen cells from 12-14-week-old B6 (wt), $A 1^{-/-}, M c l-1^{+/-}$and

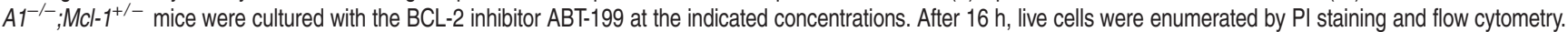
Data show a single representative experiment of two experiments of $n=3$. All data are shown as the proportion (\%) of the average number of live cells isolated from untreated cultures for each strain (\% survival) (top panel) or cells recovered/well (bottom panel) as mean \pm S.E.M. $P$-values indicated show a comparison of $A 1^{-/-}$and wt (a) and $\mathrm{A} 1^{-/-}$and $\mathrm{A} 1^{-/-} ; \mathrm{Mcl}-1^{+/-}$(b) Data were analyzed using a two-tailed Student's $t$-test. ${ }^{*} P<0.05,{ }^{* *} P<0.01,{ }^{* *} P<0.001$

haplo-insufficiency or BCL-2 inhibition by ABT-199; Figures 2c and $4 \mathrm{~b}$ ). For $\mathrm{CDCs}$, while $\mathrm{A} 1$ and $\mathrm{MCL}-1$ are limiting for survival and loss of either reduces CDC numbers on their own, ${ }^{27,32}$ this also sensitizes them to loss or antagonism of the other.

We surmise that the effects we have seen are the result of changes to mature cell survival. First, we and others have previously found that immature cells (e.g., immature B cells in $\mathrm{BM}$ or immature $\mathrm{T}$ cells in thymus) are less sensitive to BCL-2 antagonists. ${ }^{34-36}$ Second, as well as spleen, we have simultaneously looked at blood and BM for most in vivo drug experiments. As expected, we found that the reduction of cells (total, B cells, pDC) in BM (where the precursors were) was less affected compared with the periphery (blood and spleen) (Supplementary Figure 2). Therefore, even though we did not subtype immature populations here, it is highly likely that mature cells were the cells primarily affected. Third, the duration of drug treatment both in vitro (16 h) and in vivo (in most cases 1-2 days) was intentionally short to limit the 
impact of proliferation and/or differentiation. Fourth, in the experiments using $\mathrm{BCL}-2$ overexpression, $\mathrm{BM}$ analysis revealed no substantial elevation in the total number, $B$ cells $\left(\mathrm{B}_{2} 2 \mathrm{O}^{+}\right.$cells the majority of which would be immature) or pDC; therefore, this could not account for the compensatory increase of these populations in the periphery (Supplementary Figure 1).

Somewhat surprisingly, the proclivity for functional overlap among the anti-apoptotic proteins occurred irrespective of their capacity to bind the different pro-apoptotic BCL-2 family members. ${ }^{8,10,11}$ For example, BCL-2, which does not bind NOXA or BAK, could compensate for a reduction (haploinsufficiency) in MCL-1 function (which does bind NOXA and BAK). Likewise, overexpression of MCL-1, which does not bind BAD or BIK, could compensate for deficiency in BCL-2, which avidly binds these two BH3-only proteins. ${ }^{8,10,11}$ Similarly, the killing of BCL-2-dependent cell types by ABT-199 could be blocked by increased expression of MCL-1. Conversely, killing of cells by an MCL-1 inhibitor could be blocked by BCL-2 overexpression. While it is clear that preferential interactions between pro- and anti-apoptotic BCL-2 family members must exist within a physiological setting, it appears that each of these interactions alone does not solely dictate survival outcome. Rather, our data suggest that properties common or overlapping between all of the five anti-apoptotic BCL-2 proteins affecting their overall restraint of $\mathrm{BAX} / \mathrm{BAK}$ is likely to be of greater importance in controlling apoptosis.

Notably, our quantitative model only indicates that the five anti-apoptotic BCL-2 family members have functional overlap with regard to cell survival. It does not suggest identical physiological functions. Clearly their expression and protein turnover and hence level of activity are different. For example, BCL-2, BCL-XL and BCL-W are relatively long-lived proteins (half-life $\sim 20 \mathrm{~h}$ ), whereas $\mathrm{MCL}-1$ and $\mathrm{A} 1$ are short lived $(0.5-3 \mathrm{~h}) \cdot{ }^{37-40}$ Accordingly, if transcription or translation is blocked, MCL-1 and A1 functions are more quickly lost. ${ }^{38,41}$ Consequently, MCL-1 and A1 levels can be swiftly modulated in response to a range of extracellular signals, such as those provided by cytokines ${ }^{29,42-45}$ and growth factors. ${ }^{44,46,47}$ Moreover, BCL-2 and MCL-1 are constitutively expressed in many cell types, whereas $A 1$ is often only transiently expressed, for example, as an early response to antigen receptor ligation, further segregating their roles in cell survival. ${ }^{13,43}$

Our model of anti-apoptotic BCL-2 family members acting as a quantitative collective to maintain immune cell survival has important clinical implications. It warns that analysis of an individual member is not an infallible marker of drug sensitivity and propensity to undergo apoptosis. For example, BCL-2 levels alone may not predict the response of a cell population (e.g., leukemic cells) to BCL-2 antagonist drugs. Indeed, it has been noted that a high BCL-2/low MCL-1 ratio in tumor cells is a superior predictor of ABT-199 sensitivity compared to high BCL-2 expression alone. ${ }^{48}$ Our model contends that the profile of anti-apoptotic proteins, rather than any one individual present within the cell, ultimately determines drug responsiveness. For example, cells that express BCL-2 and MCL-1 but not A1, such as pDCs, would be expected to be most susceptible to BCL-2 plus MCL-1 inhibition. Conversely, cells that express BCL-2, MCL-1 and $A 1$, such as CDCs, would be predicted to be most susceptible to impairment of all three. Our quantitative model also alerts to the possibility of compensation of one family member by another. Thus, under certain conditions the amount of a particular anti-apoptotic protein may be elevated, for example, GM-CSF increases A1 expression. ${ }^{43}$ Our model also highlights that if in vitro expression of any of the anti-apoptotic $\mathrm{BCL}-2$ members does not reflect that in vivo, in vitro testing of antagonist drugs may be misleading. This is particularly germane to the shorter-lived MCL-1 and A1 proteins, which are not necessarily maintained at high levels during cell culture.

\section{Materials and Methods}

Mice and reagents. C57BL/6 wt (B6, wt), B6.Ly5.1, MCl-1/- ${ }^{+/ 9}$ VavP-BCL2 (69) transgenic $(B C L-2 \text { tg) })^{50}$ and VavP-MCl-1(33) (MCl-1 tg) transgenic ${ }^{51}$ mice were all on a B6-Ly5.2 background. $A 1^{-/-}$mice were generated on a C57BL/6 background by sequential targeting of each $A 1$ gene $(A 1 a, A 1 b$ and $A 1 d)$ as described. ${ }^{32}$ All mice were housed under specific pathogen-free conditions at the Walter and Eliza Hall Institute of Medical Research (WEHI) and were handled according to guidelines approved by the institutional Animal Ethics Committee. BM chimeras (used where specified) were generated by transplantation of $5 \times 10^{6} \mathrm{BM}$ cells into lethally $\gamma$-irradiated congenic recipient mice $(2 \times 5.5$ Gy, $3 \mathrm{~h}$ apart from a cobalt-60 source). ABT-199 (Active Biochem, Kowloon, Hong Kong) and MCL-1 inhibitor (example 185, manufactured as specified in US Patent Application No. 20150175623) were dissolved in DMSO for in vitro use. Preparation and in vivo use of ABT-199 has been previously described ${ }^{52}$ and this drug was administered at the indicated dosage by oral gavage.

Protein isolation and western blot analysis. Detection of anti-apoptotic proteins by western blot analysis was performed as described. ${ }^{27,53}$ Primary antibodies used were mouse anti-human BCL-2 (cat. no. sc-7382, Santa Cruz, Dallas, TX, USA), rat anti-MCL-1 (clone 19C4-15), rat anti-A1 (clone 6D6, in house, ${ }^{54}$ and goat anti- $\beta$-actin-HRP (cat. no. sc- 1616 HRP, Santa Cruz), the latter used as a protein loading control. Secondary antibodies used were goat anti-rat-lgHRP or goat anti-mouse-IgG1-HRP antibodies (SouthernBiotech, Birmingham, AL, USA)

Cell subset analysis, antibodies and flow cytometry. Mice were killed and single-cell suspensions of spleen prepared as described. ${ }^{26,55}$ Red blood cells were lysed in $0.168 \mathrm{M}$ ammonium chloride. For in vitro survival assays, spleen cells were enriched for DC using a nycodenz density gradient as previously described ${ }^{55}$ before $2 \times 10^{5}$ cells were cultured in 96 -well plates overnight in RPMI supplemented with $10 \%$ (vol/vol) FCS with or without inhibitors as indicated. For each experiment, wt and experimental (knockout or transgenic) splenocytes were isolated from age and sex-matched animals. Cells were treated (or left untreated) in at least triplicate within the same plate. Where data displayed as "\% survival (relative to untreated), this is calculated by dividing the total number of live cells isolated from each treated well by the average number of live cells isolated from untreated control wells. Fluorochrome-labeled antibodies against CD11c, CD11b, SIGLEC-H (ebioscience, San Diego, CA, USA), TCR $\beta$, CD8, CD4, B220, CD25, CD4, FOXP3 (ebioscience), NK1.1, NK-p46, CD45.1 and CD45.2 were used to identify leukocyte populations by flow cytometry and were purchased from BD Biosciences unless otherwise stated. Regulatory T cells (Treg) were identified by expression of intracellular FOXP3 in conjunction with CD4 and CD25 surface staining. Absolute cellularity was determined by addition of fluorochrome-conjugated calibration beads (BD Biosciences, San Jose, CA, USA) directly to samples and staining with propidium iodide was used to exclude dead cells. Samples were run on a FACS-Verse (BD Biosciences) and data analysis was performed using FlowJo 9.3.2 (Tree Star, Ashland, OR, USA).

Statistical analysis. Statistical comparisons were made using a two-tailed Student's $t$-test with Prism v.5.0 software (GraphPad, San Diego, CA, USA). Data are shown as means \pm S.E. with $P$-values $<0.05$ considered statistically significant. 


\section{Conflict of Interest}

All relevant authors are employees of The Walter and Eliza Hall Institute. This institute receives milestone payments for the development of $\mathrm{BH} 3$ mimetic drugs for therapy from Genentech and AbbVie.

Acknowledgements. We thank M Dayton, M lliopoulos, T Mason, $H$ Johnson and $\mathrm{M}$ Hancock for technical assistance. This work was supported by Rebecca $\mathrm{L}$. Cooper Foundation, National Health and Medical Research Council of Australia (NHMRC) grants and fellowships \#1037321, \#1043414, \#1080321 and \#1105209 to AML, \#461221 and \#1042629 to PB, \#1020363 and \#1016701 to AS, \#1054925 and \#1060675 to DT, \#1016647 to JGZ, \#1049720 to MH, the Leukemia and Lymphoma Society (LLS) Specialized Center of Research grant (\#7001-13 to AS), Cancer Council Victoria (CCV) Grant-in-aid (\#1102104 to AS), Austrian Academy of Science (ÖAW) Doc-fellowship (to MH), Leukemia Foundation National Research Program PhD Scholarship (to RS), NHMRC Independent Research Institutes Infrastructure Support Scheme grant (361646) and Victorian State Government Operational Infrastructure Support grant. We acknowledge the Wurundjeri people of the Kulin nation as the traditional owners and custodians of the land on which most of the work was performed.

\section{Author contributions}

Designed research: EMC, AML, IBV, DMT, JGZ and YZ. Performed research: EMC JLB, JGZ and RMS. Contributed vital new reagents or analytical tools: NSA, RLS, MJH, RBD, NDH, DS, DCSH, SC, PB and AS. Collected, analyzed and interpreted data: EMC, JLB, JGZ, RMS and AML. Wrote the manuscript: EMC, AML, AS, DMT, $\mathrm{SC}$ and $\mathrm{YZ}$

1. Czabotar PE, Lessene G, Strasser A, Adams JM. Control of apoptosis by the BCL-2 protein family: implications for physiology and therapy. Nat Rev Mol Cell Biol 2014; 15: 49-63.

2. Correia C, Lee SH, Meng XW, Vincelette ND, Knorr KL, Ding $\mathrm{H}$ et al. Emerging understanding of $\mathrm{Bcl}-2$ biology: implications for neoplastic progression and treatment. Biochim Biophys Acta 2015; 1853: 1658-1671.

3. Moldoveanu T, Follis AV, Kriwacki RW, Green DR. Many players in BCL-2 family affairs. Trends Biochem Sci 2014; 39: 101-111.

4. Strasser A, Cory S, Adams JM. Deciphering the rules of programmed cell death to improve therapy of cancer and other diseases. EMBO J 2011; 30: 3667-3683.

5. Yuan S, Akey CW. Apoptosome structure, assembly, and procaspase activation. Structure 2013; 21: 501-515.

6. O'Neill KL, Huang K, Zhang J, Chen Y, Luo X. Inactivation of prosurvival Bcl-2 proteins activates Bax/Bak through the outer mitochondrial membrane. Genes Dev 2016; 30 : 973-988.

7. Cartron PF, Gallenne T, Bougras G, Gautier F, Manero F, Vusio P et al. The first alpha helix of Bax plays a necessary role in its ligand-induced activation by the $\mathrm{BH}$-only proteins Bid and PUMA. Mol Cell 2004; 16: 807-818.

8. Kuwana T, Bouchier-Hayes L, Chipuk JE, Bonzon C, Sullivan BA, Green DR et al. BH3 domains of $\mathrm{BH} 3-o n l y$ proteins differentially regulate Bax-mediated mitochondrial membrane permeabilization both directly and indirectly. Mol Cell 2005; 17: 525-535.

9. Letai A, Bassik MC, Walensky LD, Sorcinelli MD, Weiler S, Korsmeyer SJ. Distinct BH3 domains either sensitize or activate mitochondrial apoptosis, serving as prototype cancer therapeutics. Cancer Cell 2002; 2: 183-192.

10. Chen L, Willis SN, Wei A, Smith BJ, Fletcher Jl, Hinds MG et al. Differential targeting of prosurvival $\mathrm{Bcl}-2$ proteins by their $\mathrm{BH} 3$-only ligands allows complementary apoptotic function. Mol Cell 2005; 17: 393-403.

11. Willis SN, Chen L, Dewson G, Wei A, Naik E, Fletcher Jl et al. Proapoptotic Bak is sequestered by $\mathrm{Mcl}-1$ and $\mathrm{Bcl}-\mathrm{xL}$, but not $\mathrm{Bcl}-2$, until displaced by $\mathrm{BH} 3$-only proteins. Genes Dev 2005; 19: 1294-1305.

12. Krajewski S, Bodrug S, Gascoyne R, Berean K, Krajewska M, Reed JC. Immunohistochemical analysis of Mcl-1 and Bcl-2 proteins in normal and neoplastic lymph nodes. Am J Pathol 1994; 145: 515-525.

13. Krajewski S, Bodrug S, Krajewska M, Shabaik A, Gascoyne R, Berean K et al. Immunohistochemical analysis of $\mathrm{Mcl}-1$ protein in human tissues. Differential regulation of $\mathrm{Mcl}-1$ and $\mathrm{Bcl}-2$ protein production suggests a unique role for Mcl-1 in control of programmed cell death in vivo. Am J Pathol 1995; 146: 1309-1319.

14. Vikstrom I, Carotta S, Luthje K, Peperzak V, Jost PJ, Glaser S et al. Mcl-1 is essential for germinal center formation and B cell memory. Science 2010; 330: 1095-1099.

15. Oltersdorf T, Elmore SW, Shoemaker AR, Armstrong RC, Augeri DJ, Belli BA et al. An inhibitor of Bcl-2 family proteins induces regression of solid tumours. Nature 2005; 435 : 677-681.

16. Tse C, Shoemaker AR, Adickes J, Anderson MG, Chen J, Jin S et al. ABT-263: a potent and orally bioavailable Bcl-2 family inhibitor. Cancer Res 2008; 68: 3421-3428.
17. van Delft MF, Wei AH, Mason KD, Vandenberg CJ, Chen L, Czabotar PE et al. The BH3 mimetic ABT-737 targets selective $\mathrm{Bcl}-2$ proteins and efficiently induces apoptosis via Bak Bax if Mcl-1 is neutralized. Cancer Cell 2006; 10: 389-399.

18. Souers AJ, Leverson JD, Boghaert ER, Ackler SL, Catron ND, Chen J et al. ABT-199, a potent and selective $\mathrm{BCL}-2$ inhibitor, achieves antitumor activity while sparing platelets. Nat Med 2013; 19: 202-208.

19. Roberts AW, Davids MS, Pagel JM, Kahl BS, Puvvada SD, Gerecitano JF et al. Targeting BCL2 with venetoclax in relapsed chronic lymphocytic leukemia. N Engl J Med 2016; 374 311-322.

20. Stilgenbauer S, Eichhorst B, Schetelig J, Coutre S, Seymour JF, Munir T et al. Venetoclax in relapsed or refractory chronic lymphocytic leukaemia with $17 \mathrm{p}$ deletion: a multicentre, openlabel, phase 2 study. Lancet Oncol 2016; 17: 768-778.

21. Roberts AW, Seymour JF, Brown JR, Wierda WG, Kipps TJ, Khaw SL et al. Substantial susceptibility of chronic lymphocytic leukemia to BCL2 inhibition: results of a phase study of navitoclax in patients with relapsed or refractory disease. J Clin Oncol 2012; 30 : 488-496.

22. Mason KD, Carpinelli MR, Fletcher JI, Collinge JE, Hilton AA, Ellis S et al. Programmed anuclear cell death delimits platelet life span. Cell 2007; 128: 1173-1186.

23. Zhang $\mathrm{H}$, Nimmer PM, Tahir SK, Chen J, Fryer RM, Hahn KR et al. Bcl-2 family proteins are essential for platelet survival. Cell Death Differ 2007; 14: 943-951.

24. Bouillet $P$, Cory S, Zhang LC, Strasser A, Adams JM. Degenerative disorders caused by Bcl-2 deficiency prevented by loss of its BH3-only antagonist Bim. Dev Cell 2001; 1 : 645-653

25. Nakayama K, Nakayama K, Negishi I, Kuida K, Sawa H, Loh DY. Targeted disruption of Bcl-2 alpha beta in mice: occurrence of gray hair, polycystic kidney disease, and lymphocytopenia Proc Natl Acad Sci USA 1994; 91: 3700-3704

26. Carrington EM, Vikstrom IB, Light A, Sutherland RM, Londrigan SL, Mason KD et al. BH3 mimetics antagonizing restricted prosurvival $\mathrm{Bcl}-2$ proteins represent another class of selective immune modulatory drugs. Proc Natl Acad Sci USA 2010; 107: 10967-10971.

27. Carrington EM, Zhang JG, Sutherland RM, Vikstrom IB, Brady JL, Soo P et al. Prosurvival Bcl-2 family members reveal a distinct apoptotic identity between conventional and plasmacytoid dendritic cells. Proc Natl Acad Sci USA 2015; 112: 4044-4049.

28. Peperzak V, Vikstrom I, Walker J, Glaser SP, LePage M, Coquery CM et al. Mcl-1 is essentia for the survival of plasma cells. Nat Immunol 2013; 14: 290-297.

29. Sathe P, Delconte RB, Souza-Fonseca-Guimaraes F, Seillet C, Chopin M, Vandenberg CJ et al. Innate immunodeficiency following genetic ablation of $\mathrm{Mcl} 1$ in natural killer cells. Nat Commun 2014; 5: 4539.

30. Pierson W, Cauwe B, Policheni A, Schlenner SM, Franckaert D, Berges J et al. Antiapoptotic $\mathrm{Mcl}-1$ is critical for the survival and niche-filling capacity of Foxp3(+) regulatory T cells. Nat Immunol 2013; 14: 959-965.

31. Kotschy A, Szlavik Z, Murray J, Davidson J, Maragno AL, Le Toumelin-Braizat G et al. The MCL1 inhibitor S63845 is tolerable and effective in diverse cancer models. Nature 2016; 538 477-482.

32. Schenk RL, Tuzlak S, Carrington EM, Zhan Y, Heinzel S, Teh CE et al. Characterisation of mice lacking all functional isoforms of the pro-survival BCL-2 family member A1 reveals minor defects in the haematopoietic compartment. Cell Death Differ 2017; 24: 534-545.

33. Tuzlak S, Schenk RL, Vasanthakumar A, Preston SP, Haschka MD, Zotos D et al. The BCL-2 pro-survival protein $\mathrm{A} 1$ is dispensable for $\mathrm{T}$ cell homeostasis on viral infection. Cell Death Differ 2017; 24: 523-533.

34. Vikstrom IB, Slomp A, Carrington EM, Moesbergen LM, Chang C, Kelly GL et al. MCL-1 is required throughout $\mathrm{B}$-cell development and its loss sensitizes specific B-cell subsets to inhibition of BCL-2 or BCL-XL. Cell Death Dis 2016; 7: e2345.

35. Khaw SL, Merino D, Anderson MA, Glaser SP, Bouillet P, Roberts AW et al. Both leukaemic and normal peripheral $B$ lymphoid cells are highly sensitive to the selective pharmacological inhibition of prosurvival Bcl-2 with ABT-199. Leukemia 2014; 28: 1207-1215.

36. Merino D, Khaw SL, Glaser SP, Anderson DJ, Belmont LD, Wong $\mathrm{C}$ et al. Bcl-2, Bcl-x(L), and Bcl-w are not equivalent targets of ABT-737 and navitoclax (ABT-263) in lymphoid and leukemic cells. Blood 2012; 119: 5807-5816.

37. Yang $T$, Kozopas KM, Craig RW. The intracellular distribution and pattern of expression of Mcl-1 overlap with, but are not identical to, those of Bcl-2. J Cell Biol 1995; 128: 1173-1184.

38. Adams KW, Cooper GM. Rapid turnover of mcl-1 couples translation to cell survival and apoptosis. J Biol Chem 2007; 282: 6192-6200.

39. Akgul C, Moulding DA, White MR, Edwards SW. In vivo localisation and stability of human Mcl-1 using green fluorescent protein (GFP) fusion proteins. FEBS Lett 2000; 478: 72-76.

40. Herold MJ, Zeitz J, Pelzer C, Kraus C, Peters A, Wohlleben G et al. The stability and antiapoptotic function of $A 1$ are controlled by its $C$ terminus. J Biol Chem 2006; 281: 13663-13671.

41. Kucharczak JF, Simmons MJ, Duckett CS, Gelinas C. Constitutive proteasome-mediated turnover of $\mathrm{Bfl}-1 / \mathrm{A} 1$ and its processing in response to TNF receptor activation in FL5.12 proB cells convert it into a prodeath factor. Cell Death Differ 2005; 12: 1225-1239.

42. Chao JR, Wang JM, Lee SF, Peng HW, Lin YH, Chou CH et al. mcl-1 is an immediate-early gene activated by the granulocyte-macrophage colony-stimulating factor (GM-CSF) signaling pathway and is one component of the GM-CSF viability response. Mol Cell Biol 1998; 18: 4883-4898

43. Lin EY, Orlofsky A, Berger MS, Prystowsky MB. Characterization of A1, a novel hemopoieticspecific early-response gene with sequence similarity to bcl-2. J Immunol 1993; 151 1979-1988. 
44. $\mathrm{He} \mathrm{CH}$, Waxman $\mathrm{AB}$, Lee $\mathrm{CG}$, Link $\mathrm{H}$, Rabach ME, Ma B et al. Bcl-2-related protein $\mathrm{A} 1$ is an endogenous and cytokine-stimulated mediator of cytoprotection in hyperoxic acute lung injury. J Clin Invest 2005; 115: 1039-1048.

45. Olsson Akefeldt S, Maisse C, Belot A, Mazzorana M, Salvatore G, Bissay N et al. Chemoresistance of human monocyte-derived dendritic cells is regulated by IL-17A. PloS ONE 2013; 8: e56865.

46. Le Gouill S, Podar K, Amiot M, Hideshima T, Chauhan D, Ishitsuka K et al. VEGF induces Mcl-1 up-regulation and protects multiple myeloma cells against apoptosis. Blood 2004; 104 2886-2892.

47. Zhang J, D'Ercole AJ. Expression of Mcl-1 in cerebellar granule neurons is regulated by IGF-I in a developmentally specific fashion. Brain Res Dev Brain Res 2004; 152: 255-263.

48. Touzeau C, Dousset C, Le Gouill S, Sampath D, Leverson JD, Souers AJ et al. The Bcl-2 specific $B H 3$ mimetic ABT-199: a promising targeted therapy for $t(11 ; 14)$ multiple myeloma. Leukemia 2014; 28: 210-212.

49. Rinkenberger JL, Horning S, Klocke B, Roth K, Korsmeyer SJ. Mcl-1 deficiency results in peri-implantation embryonic lethality. Genes Dev 2000; 14: 23-27.
50. Ogilvy S, Metcalf D, Print CG, Bath ML, Harris AW, Adams JM. Constitutive Bcl-2 expression throughout the hematopoietic compartment affects multiple lineages and enhances progenitor cell survival. Proc Natl Acad Sci USA 1999; 96: 14943-14948.

51. Campbell KJ, Bath ML, Turner ML, Vandenberg CJ, Bouillet P, Metcalf D et al. Elevated Mcl-1 perturbs lymphopoiesis, promotes transformation of hematopoietic stem/progenitor cells, and enhances drug resistance. Blood 2010; 116: 3197-3207.

52. Vandenberg CJ, Cory S. ABT-199, a new Bcl-2-specific BH3 mimetic, has in vivo efficacy against aggressive Myc-driven mouse lymphomas without provoking thrombocytopenia. Blood 2013; 121: 2285-2288.

53. Koenen P, Heinzel S, Carrington EM, Happo L, Alexander WS, Zhang JG et al. Mutually exclusive regulation of $T$ cell survival by IL-7R and antigen receptor-induced signals. Nat Commun 2013; 4: 1735

54. Lang MJ, Brennan MS, O'Reilly LA, Ottina E, Czabotar PE, Whitlock E et al. Characterisation of a novel A1-specific monoclonal antibody. Cell Death Dis 2014; 5: e1553.

55. Vremec D, Pooley J, Hochrein H, Wu L, Shortman K. CD4 and CD8 expression by dendritic cell subtypes in mouse thymus and spleen. J Immunol 2000; 164: 2978-2986.

Supplementary Information accompanies this paper on Cell Death and Differentiation website (http://www.nature.com/cdd) 